\title{
The Author Replies...
}

\section{Stepping Away from the Utopias: Sin and the Myth of Progress in Matters of Pedagogy}

\section{Más Allá de las Utopias: El Pecado y el Mito del Progreso en Asuntos Pedagogicos}

\section{Progression à Partir de l'Utopias : Le Péché de et le Mythe du Progrès dans les Sujets de la Pédagogie}

\section{Theodore Christou}

Queen's University

\begin{abstract}
$A$ LBert camus saw sisyphus in us all. ${ }^{1}$ Each of us he thought, is a Sisyphus, who to varying degrees is eternally tormented and belaboured. This mythological figurelike Marsyas, like Prometheus, like Ixion, like Echo, like Narcissus-challenged or offended the divine inhabitants of Olympus. Sisyphus, condemned by Zeus to eternally roll a stone up a steep and sloping hill only to watch the rock slip and slide back down to the bottom again was curiously, in Camus' eyes, smiling. Sisyphus had come to understand his plight and take some measure of pleasure from the exhaustiveness of his torment. The disappointment that would be intertwined with the inevitable and predestined failure of his endeavours, with time, faded. He ceased to expect that the stone he pushed would actually perch, howsoever precariously, at the acme, or top of the hill. Sisyphus understood that his labours, albeit wrought of compulsion, would not end perfectly and penultimately in triumph. Each time he, aching in muscle and bone, balanced the rock atop the mount, the stone rolled back down again, raising billows of dust and smoke, ending with a thud. But he ceased to assume that it would.

The top of the mount ceased to be an ambition. The mountaintop was no Eden. He ceased striving for a false utopia. As pedagogues, our march towards the many
\end{abstract}


pedagogical utopias that allure is not a linear and progressive one. In fact, we often forget that utopia means, according to its Greek roots, no place. There is no Camelot; the kingdom of Prester John is equally mythic. As Thomas More stated, in order "to be a utopian, to live for the creation of a fantastic and unreal world, was to live in no place, to remove oneself from reality." ${ }^{2}$ No antecedent rests in human history of a perfect institution, perfect school, perfect examination, or perfect curriculum that we might emulate. The rambunctious and zealous notion that we can tinker towards any sort of utopia, in a so-called information age or in hypothetical ages of epic, reason, and romance, is folly. Folly is the idealization of humanity's, albeit tremendous, technological and scientific advances and the neglect of our many moral, ethical, and brutal catastrophes. We progress; indeed we leap and fly. We also fall; we drown and decay. Revolutions can reform corrupt and unjust institutions; pursued without compassion and a modesty of intention, however, they can turn fundamentalist, extremist, and vain.

Fernando Bárcena reminds us of Jonathan Little's Maximilian Aue who kills in a concentration camp by day and reads sentimental literature by night. Joseph Conrad provided us with an equally complex character in Heart of Darkness. Kurtz is intelligent, cultured, and representative of "pity, and science, and progress." ${ }^{3}$ His intentions, when he first arrives at the trading station in the Congo, appear virtuous and noble. By the end of the book, Kurtz's solipsism and megalomania have overcome him. He displays the heads of murdered natives on spikes as testaments to his power. His modesty is lost. Conrad represents Kurtz as one who suppresses and imposes change. His education and his worldview, he thought, are better than the Congolese. This, largely, represents the attitudes of imperial armies and oppression for most of human history. This also, although not to the same violent degree, epitomizes the position that the arrogant and immodest educator takes in relation to the learner. Because Kurtz felt that he knew and that the natives surrounding his remote trading post did not, and because relationship with the Congolese was in no way iterative and reciprocal, it was bound to end unhappily and tragically.

Daedalus, the caring father and teacher, warning Icarus, not to soar too high on the waxen wings he had crafted, also cautions us about the perils involved in the vainglory of knowledge. Our ingenuity is great but not infallible. Our teaching methods, our curricula, our tests and examinations, our standards, and our facilities are testaments to the cunning and resourcefulness of educationists. But if we imagine that these are stepping-stones to some educational Eden, we are mistaken. The delusion that our schools are progressing to perfected states is misguided. There is no pedagogical perfection, just as there is no moral perfection. Belief to the contrary is "magical thinking ... [as] there is little in science or history to support this idea. Human individuals can make moral advances, as can human societies, but they also make moral reverses ... we alternate between periods of light and periods of darkness." 4

We must, rooted in an ethically defensible view of the world and of the educational process, strive for more and dream for better. But our yearning for progress must never veer into the domain of immodest, authoritarian, and presumptive knowledge claims. Milton's Satan, we have seen, like Icarus noted above, also plummeted. The 
(oft-cited and rarely heeded) ancient call of the Greeks for pan metron ariston (it is excellent for all things to be in moderation) meant little in practice to either Icarus or to Satan. Because they held some knowledge and had made some advances, howsoever contingent or contextual, they assumed they could know all and progress infinitely. Industriousness, innovativeness, and courage are great, but the laws of the cosmos, so vast as to forever remain unknown to us, are greater still.

If one thing is certain, it is that the faith in educational progress has been exploited and continues to be the stuff that vast riches are made from. Peddlers of pedagogical miracles, whether they are textbooks sequencing lessons, programs to promote cooperative initiatives, or pharmaceuticals to tame learners into obedience, sell their wares by preying on the idyllic wishes of parents and teachers. Such and such program will do away with racism. This or that initiative will raise test scores. Some people are making mints of money. And while this is not a cry for educationists to raise their whips and chase the moneylenders from the holy temple, it is important that we do not pay a fool's ransom for every schooling miracle being sold.

The pedagogical lessons we could extract from mythology and from literature are indeed, as Fernando Bárcena made evident in his eloquent and thoughtful response to my essay Satan or Socrates: The Perils of Excessive Pride in Pedagogy, are vast and sundry. These sources, human allegories representing the immensity of the universe relative to our own (necessarily and logically shallow) understanding of it, provide us much space for reflection and contemplation on pedagogical matters. This reflective space resembles the parables of ancients and the whispered words of a grandparent to a child. It is marvelous to contemplate such parables and tales, but it is only with the passing of time and the yielding to frustrations, anxieties, and experience that the moral kernels within them can be digested and understood. This understanding requires a certain levity and a great deal of modesty. Sisyphus, for example, could not begin to laugh at himself immediately after assuming his punishment. Surely he cried, and blasphemed, and crumpled into the dusty earth before he could learn to smile at his plight.

Reflecting humbly upon the triumphs and defeats of our pedagogical, moral, and ethical endeavours is much like contemplating the allegories and mythologies of old; the words and the lessons imbued in them draw us with the beauty of Narcissus' image in the still waters of a mirrored lake. The attraction is a resemblance and a recognition. Experience - the playing out of what Fernando Bárcena named the "learner's possibilities of action" - develops a "common world" between the past (even remote or literary and symbolic) and the lived present. We conserve the past not merely by reading it and by speaking it, but also by living it. We embrace the newness of opportunity, whether it be generational, educational, or pedagogical, and at the same time we must promote "the unforseen" with "tenacious humility." We must both query our yesterdays and respond to our uncertain tomorrows. This is necessary for us both as teachers and as learners, for the humble educator is eager to learn and the heroic learner is looking to teach.

It is heroic, too, Kierkegaard reminds us, to stand as the soldier does upon the battlefield, full of fear and trembling, alert, attentive, faithful. It takes tremendous 
faith to acknowledge ignorance and to be modest as an educator. This is particularly true when the teacher is positioned as knower and the learner as the vessel to be filled by that knowledge which is fit to be bestowed. Before professing knowledge about anything or anyone else, educators must examine their own practices, institutions, and norms critically. This realistic, critical reflection, humbly and modestly engaged in, should dispell any idea that all things are progressing to some perfected state in our schools. Self-knowledge, the need to examine one's self critically, in accordance with the Greek command to 'know thyself', is tantamount for educators, no matter how many qualifications or years of experience garland their curriculum vitae. Kiergegaard expresses this most poignantly: "What is education? I should suppose that education was the curriculum one had to run through in order to catch up with oneself, and he who will not pass through this curriculum is helped very little by the fact that he was born in the most enlightened age." ${ }^{5}$

It is imperative to remember the notion that oudis anamartitos, or, no one is without sin. This notion - sin - while perhaps unsettling in an essay on education holds major pedagogical potentialities. It "is a stark acknowledgment that we can never be omnipotent, that we are bound and limited by human flaws and self-interest. The concept of sin is a check on the utopian dreams of a perfect world. It prevents us from believing in our own perfectibility." "To revel in our pedagogical advancements and to be the prophets of educational utopias is to turn away from the tumult and the imperfections that are real parts of schooling's history. Turning our backs on the notion of sin and relegating it to the dusty attic of Byzantine religious concepts is to lose sight of its usefulness in promoting a modest approach to educational reflection.

An educational sin, then, is not blaspheming towards Olympian deities, which in mythology was punished (mostly, quite brutally) as hubris. It is an affront to the lived experience of teaching and learning, which is humbling even during the best of lessons. An educational sin is the brandishing of jargon and it is the threatening with slogans. It is the enthronement of statistics and quantitative measurements. It is the hijacking of pedagogical knowledge by the universities, bureaucrats, and administrators in spite of the fact that teaching and learning are as ancient and as widespread as is humanity. It is an educational sin to purport that technology makes for better schooling; many great minds were cultivated and developed in one-room schoolhouses and, before that, in fields, homes, and agoras. Wherever people are, learning is happening. Much of it is useful, sensible, and evocative. Relatively little of it is contained within our schools. There is no monopoly on instruction.

Yet there are victories to be won and progress to be made for pedagogical freedoms, strategies, ideas, and opportunities. These triumphs need to be celebrated, built upon, and remembered. We must equally set up monuments to our defeats, lest we forget them. The danger lies in ignoring the many flaws in our systems of schooling and in the masking of these for political, economic, or rhetorical gain. Our pedagogical Edens, no matter how constructed, will always be gated territories that leave some aspects of educational reality on the outside. We have never seen such utopias and, as much as we might aspire to a land of educational milk and honey, we never shall construct such a place. 
Despite all our successes, our schools cannot and will not be perfect. That is not to say that we should not dream for more and strive for progress. It is to argue that we must proceed with hearts full of trepidation. For we are as prone to educational arrogance and sin as we are to modesty and humble self-reflection. Thinking about education is an epic enterprise, and improvements can only be made with foreknowledge and expectation that errors will also occur. The crowning and enthronement of any knowledge is horribly presumptive. Odysseus, protagonist of the Odyssey and victor at Troy, returned home to Ithaca after a full ten years of warring and another ten years of voyaging to find his house full of suitors for his throne and wife. Even after cleansing his house of threat (say many continuations of the Homeric epic), he wrestled with his own internal demons until the end of his days. This perpetuation of his struggles represents the human condition and, as such, was inevitable. Sisyphus, smiling, could have told him as much.

But there remains more in the sum and conclusion for educationists than a Sisyphus who is resigned to mocking his awful fate. There are, burning brightly in the embers of all the extinguished Edens the moral imperatives of caring and of justice. Teaching is necessarily a deeply and profoundly ethical activity. ${ }^{7}$ Because human history is so replete with arrogance and error, and because our desire for utopias has driven us to fanaticism, holocaust, and genocide in the past, we must cultivate, above all, compassion. This principle, as innate in us as any other, is the checkpoint that balances the vulgar, the relativistic, and the nihilistic. It forces us to see beyond the confines of the $I$ and embrace the we, which is all very fragile, and vast, and complex. It is humbling to abandon the seeming security of our knowledge claims. Yet when the educator approaches the learning context reverently, with empathy and with compassion for the learner, without pretense of perfected or complete knowledge, and with a sympathetic understanding that both the other and the self are imperfect human beings, the potentialities for powerful learning need not be modest at all.

It is not immodest to dream. Nor is it vulgar to aspire to a better world. A vision of the world that is bereft of revolution, idealism, and hope would be a dessicated and fundamentally ahistorical one. Similarly, education that is not rooted in social justice and committed to compassion and love is ugly, cold, and inhuman. When we do not aspire to some comprehensive ideal that is framed in terms of ethical principles, we move aimlessly and hopelessly. Sisyphus needed his mount and his rock in order to give purpose and some semblance of meaning to his existence; Odysseus was waylaid numerous times without losing sight of his Ithaca and his Penelope. We too, educationists, need lofty, lovely aims.

But we must never pursue these with the verve of fundamentalists or with the vanity of imperialist aggression. Our revolutions, pedagogical or otherwise, fought for higher purposes can, when rooted in modesty and and committed to justice, improve the conditions for schooling and life. But none, not even the most admired idealists and the most celebrated of progressives, are without sin. 


\section{Notes}

1. Albert Camus, The Myth of Sisyphus and Other Essays (New York: Vintage, 1991).

2. Chris Hedges, I Don't Believe in Atheists (New York: Free Press, 2008), 11.

3. Joseph Conrad, Heart of Darkness (New York: Penguin, 1989), 55.

4. Hedges, I Don't Believe in Atheists, 10.

5. Søren Kierkegaard, Fear and Trembling, http://www.mv.helsinki.fi/home/tkannist/Etexts/Kierkegaard/fear.htm (accessed August 3, 2008).

6. Hedges, I Don't Believe in Atheists, 14.

7. Rosa Bruno-Jofré, Dean's Message: Welcoming Remarks to the Class of 2007/2008, http://educ.queensu.ca/about/dean/welcome/index.shtml (accessed August 7, 2008). 